\title{
Manipulating thermal stress on rocky shores to predict patterns of recruitment of marine invertebrates under a changing climate
}

\author{
Justin A. Lathlean*, Todd E. Minchinton \\ Institute for Conservation Biology and Environmental Management \& School of Biological Sciences, \\ University of Wollongong, New South Wales 2522, Australia
}

\begin{abstract}
For rocky intertidal organisms, temperature is often considered the most influential factor governing early survival and growth. Nevertheless, our review of the literature revealed that few studies have manipulated temperatures in the field to test for effects on these critical early life history processes. Here, we present the results from a novel manipulation of substratum temperature using settlement plates of different colour (black, grey and white) and infrared measurements of temperature to test hypotheses that temperature influences the early survival and growth of recent settlers of the intertidal barnacle Tesseropora rosea. Mean surface temperatures of black and grey plates were as great as $5.8^{\circ} \mathrm{C}$ (on average $2.2^{\circ} \mathrm{C}$ ) and $4.8^{\circ} \mathrm{C}$ (on average $1.6^{\circ} \mathrm{C}$ ) hotter than white plates across the sampling period, respectively. Cooler, white plates had significantly greater settlement and early growth than hotter, black plates, but differences in plate temperature did not significantly influence early survival or recruitment, though patterns were consistent with thermal variability. Comparisons between grey coloured natural rock and plates indicate that grey plates thermally mimic natural rock. Nevertheless, on average, more than twice as many larvae settled on plates than on natural rock, but early post-settlement survival on natural rock was double that on plates, suggesting that this artificial surface may not adequately capture the natural variability in early life history processes. Regardless, our simple and repeatable thermal manipulation represents a useful tool for experimentally investigating the effects of temperature on recruitment processes and simulating future temperature variability associated with climate change.
\end{abstract}

KEY WORDS: Climate change $\cdot$ Early mortality $\cdot$ Safety Walk® tape $\cdot$ Settlement $\cdot$ Barnacle Resale or republication not permitted without written consent of the publisher

\section{INTRODUCTION}

It is not surprising that climate change research has increased rapidly over the past 2 decades (Harley et al. 2006) since associated increases in global temperatures are expected to alter the physiology, ecology and biogeography of organisms worldwide (Helmuth et al. 2006b). At the heart of this research is understanding how physical parameters, such as rising atmospheric temperature and extreme temperature events, alter physiological processes that translate into long term shifts in the demography of populations and assembly of communities (Denny \& Helmuth 2009, Helmuth et al. 2010). This is particularly true for rocky intertidal organisms, for which factors such as the tidal cycle, micro-topography, wind speed, air temperature and solar radiation cause body temperatures to fluctuate by $>20^{\circ} \mathrm{C}$ within a few hours and differ significantly between individuals only centimetres apart (Denny et al. 2011, Helmuth et al. 2011). This thermal variability makes wave-swept rocky shores excellent systems to test and model the predicted biological impacts of increased temperatures associated with climate change (Pitt et al. 2010, Helmuth et al. 2011, Wethey et al. 2011). In common with most species, it is the early life history stages of benthic invertebrates that are most vulnerable to changes in temperature (Gosselin \& Qian 1997, Hunt 
\& Scheibling 1997), yet few studies have measured the responses of newly settled larvae or recruits to temperature manipulations in the field (see Table 1).

In reviewing the literature, we found 76 studies that have examined the effects of temperature on rocky intertidal invertebrates in the field (Table 1). The majority of field-based experimental studies investigating the role of temperature on intertidal invertebrates do so by indirectly manipulating temperatures. Moreover, only 23 include an experimental component that manipulates temperature, and of these, 16 manipulated temperature indirectly by either shading or transplanting individuals across intertidal heights. Such indirect manipulations typically do not control for other potentially confounding factors, such as levels of UV exposure that can vary with intertidal height (Harley \& Helmuth 2003, Gosselin \& Jones 2010). Additionally, only 23 studies assessed the effect of temperature on early life history stages of invertebrates, and only 5 of these included an experimental component. In these 5 studies, temperatures that were altered by manipulating shade (Bertness 1989, Bertness et al. 1999b), macroalgae (Bertness et al. 1999a), substratum size (Gedan et al. 2011) and substratum type (Shanks 2009) influenced the early life history processes of barnacles (Table 1). Only 1 study directly manipulated temperature, and this was achieved through the use of propane heaters and assessed the relationship between macroalgal diversity and resilience (Allison 2004).

The finding that field studies have rarely assessed the effect of temperature variation on the early life history stages of intertidal invertebrates is surprising because settlers and recruits are known to be particularly vulnerable to heat and desiccation stress (Gosselin \& Qian 1997, Hunt \& Scheibling 1997), and early life history processes play important roles in structuring the size and distribution of adult populations (Connell 1985, Minchinton \& Scheibling 1991, Caley et al. 1996, Menge 2000). This gap in research is most likely due to a combination of difficulties, including teasing apart multiple factors that influence body temperatures of intertidal invertebrates (Helmuth et al. 2006b), undertaking field measurements of early life history processes (Keough \& Downes 1982, Minchinton \& Scheibling 1993) and measuring temperature variability at a scale relevant to individual settlers.

Studies examining early life history processes and quantifying patterns of recruitment of intertidal invertebrates have often used, with great success, artificial settlement surfaces, such as ceramic tiles and PVC plates covered in Safety Walk ${ }^{\circledR}$ tape (SWT) (Farrell et al. 1991, Lagos et al. 2005, Broitman et al. 2008). This research has shown that differences in substratum characteristics (e.g. temperature, texture) between artificial and natural rock surfaces can influence early mortality and recruitment (e.g. Raimondi 1988, McGuinness 1989, Herbert \& Hawkins 2006, Shanks 2009, Menge et al. 2010). For example, Shanks (2009) found that Plexiglas plates covered in grey SWT were significantly hotter and caused higher early post-settlement mortality in comparison to cooler ceramic tiles, and Menge et al. (2010) discovered that barnacle settlement was greater on plates covered in SWT compared to natural rock. These studies suggested that plates covered with SWT could be a useful way to manipulate temperature at a single intertidal height on rocky shores and to test for effects on early life history processes. Such an experimental manipulation would also benefit from recently developed infrared imaging techniques used to quantify fine-scale variation in both physical and biological characteristics of rocky intertidal shores (Murphy et al. 2006, Underwood \& Murphy 2008, Chapperon \& Seuront 2011, Cox \& Smith 2011). The advantage of such infrared sensing is that temperature variability can be assessed at spatial scales relevant to newly settled benthic marine invertebrates.

The primary aim of the present study was to use artificial settlement plates covered with SWT of different colours to manipulate substratum temperatures at a single tidal height on a rocky shore and to examine the effects on settlement, early post-settlement growth, survival and recruitment of the barnacle Tesseropora rosea. A secondary objective was to investigate whether the thermal properties of settlement plates covered in SWT are similar to those of natural rock. We achieved this by comparing settlement, early post-settlement growth, survival and recruitment of $T$. rosea on natural rock to the artificial settlement plates.

\section{MATERIALS AND METHODS}

\section{Study region and species}

Our study focussed on the barnacle Tesseropora rosea on an exposed rocky intertidal shore at Garie Beach (3410' 38.1" S, 15103' 57.8" E) near Sydney in southeastern Australia. The rocky platform at Garie Beach is primarily composed of siltstone and is grey in colour. The platform has an east to northeasterly aspect and an overall slight to moderate ( 0 to $20^{\circ}$ ) inclination. In situ measurements recorded by 


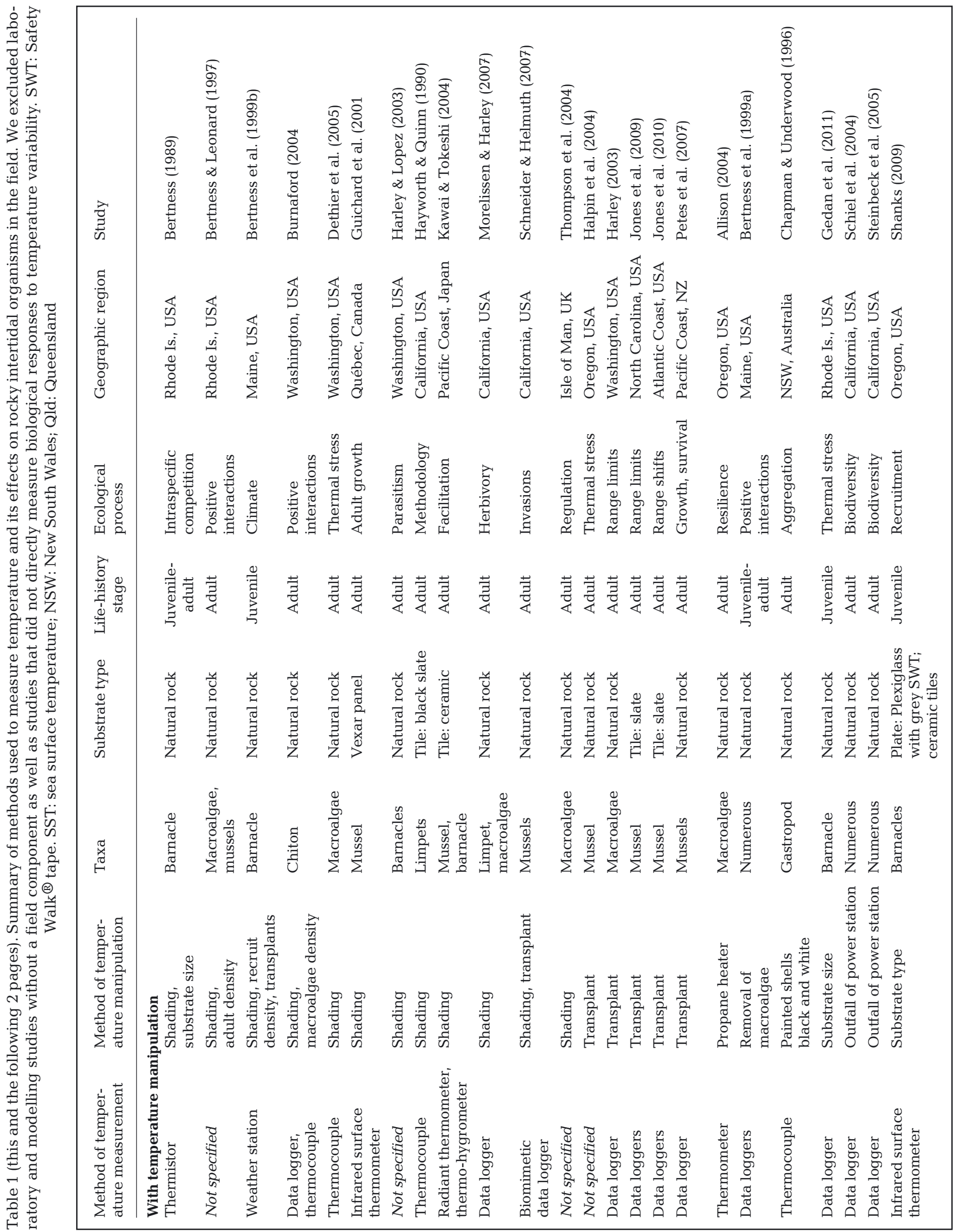




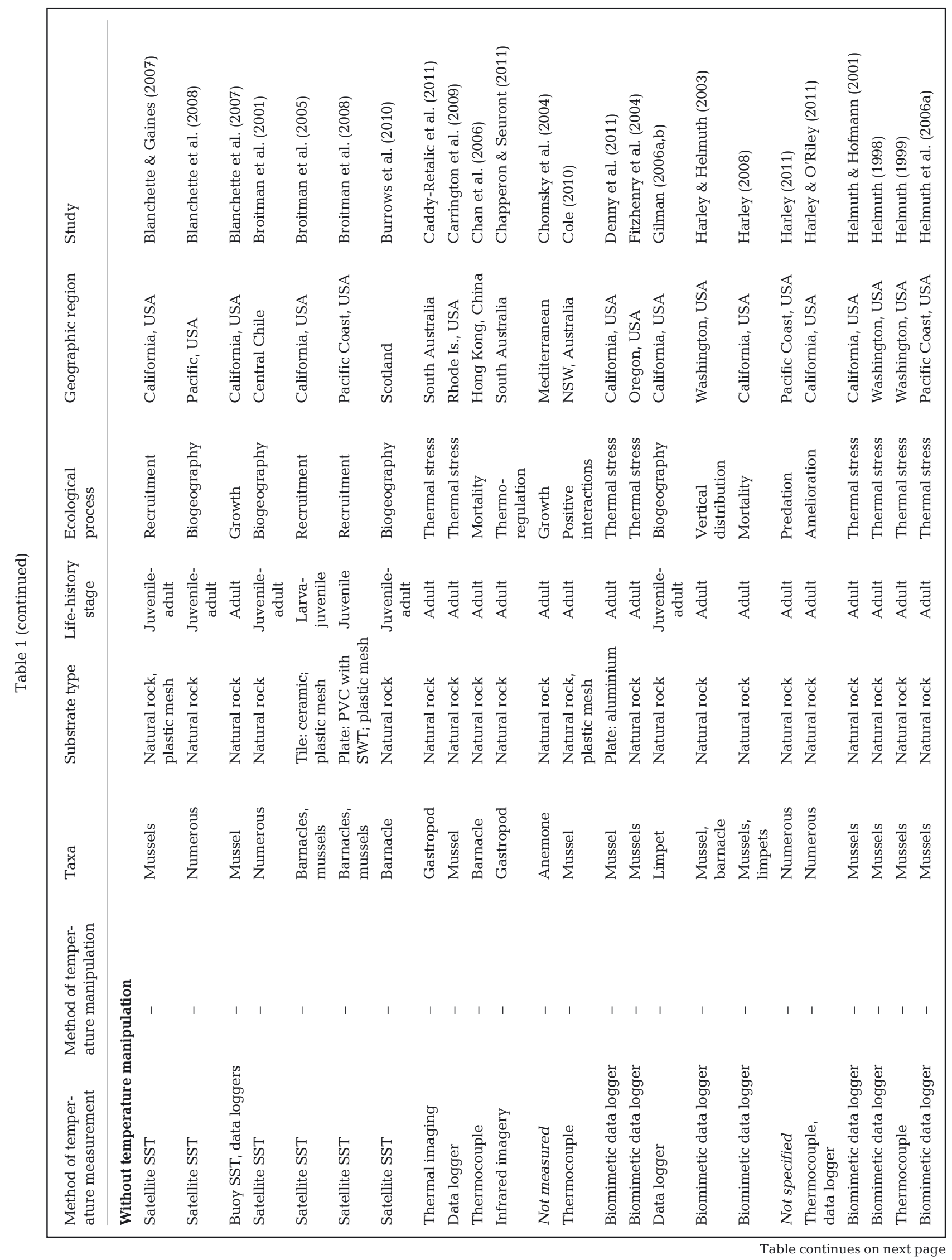




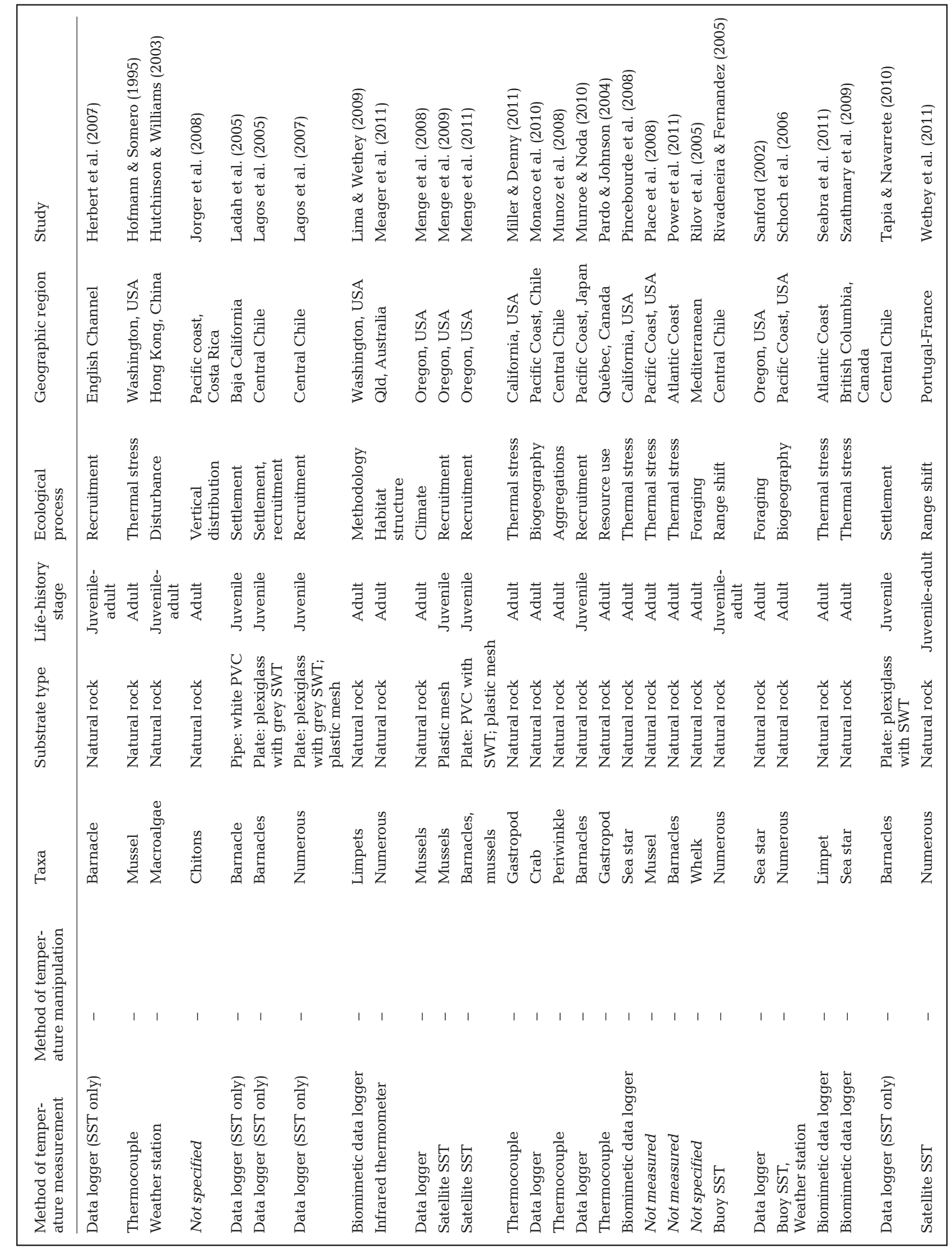


TidbiT ${ }^{\circledR}$ v2 Temp data loggers (Onset Stowaway logger, model UTBI-001, accuracy $\pm 0.2^{\circ} \mathrm{C}$ ) every $10 \mathrm{~min}$ showed that mid-intertidal air temperatures at Garie Beach (including both day- and night-time temperatures) varied between 11.9 and $38.6^{\circ} \mathrm{C}$ and were on average $20.8^{\circ} \mathrm{C}$ during the sampling period (8 March to 20 April 2011). Over a 12 mo period, maximum and minimum air temperatures at Garie Beach were $50.8^{\circ} \mathrm{C}$ and $5.5^{\circ} \mathrm{C}$, respectively (Lathlean et al. 2011). Wave heights in this region are greatest and most variable during February, March and June and at times may exceed $4 \mathrm{~m}$ (Short \& Trenaman 1992). East to southeasterly waves are the most common and occur year round, with easterly waves peaking in March and November and southeasterly waves peaking in May and November (Short \& Trenaman 1992). T. rosea on this headland is abundant, and populations have been continuously monitored over the past 5 yr (Hidas et al. 2010, Lathlean et al. 2010). We have observed a distinct breeding and settlement period between January and June each year with larvae usually arriving in 3 distinct pulses, once in January, then from late February to early April and then again in May (Denley \& Underwood 1979, Lathlean et al. 2010).

\section{Manipulation of substratum temperatures}

After preliminary investigations, we developed 4 treatments to manipulate substratum temperatures and investigate effects on the early life history processes of Tesseropora rosea. The first 3 treatments were artificial surfaces $(10 \times 10 \times 0.5 \mathrm{~cm})$ of different colour: (1) grey PVC plates covered with black SWT (3M Safety Walk ${ }^{\mathrm{TM}}$ Slip-Resistant Material General Purpose 600 series), (2) grey PVC plates covered with clear SWT and (3) white acrylic plates covered with clear SWT (Fig. 1a,b,c). The fourth treatment was natural rock $(10 \times 10 \mathrm{~cm}$ quadrats $)$ that was initially cleared of all invertebrates and biofilm using a chisel and metal brush (hereafter referred to as rock) (Fig. 1d).

The first 3 treatments were used to manipulate temperature and test for effects on settlement, early post-settlement growth, survival and recruitment of Tesseropora rosea. The fourth treatment allowed com- parisons between natural rock and artificial surfaces. One advantage of using plates with SWT to manipulate substratum temperature is that all substrata have identical surface textures. Differences in colour among artificial surfaces would not be expected to influence processes after barnacle settlement, other than by influencing substratum temperatures. Indeed, Caffey (1982) has shown that there was no influence

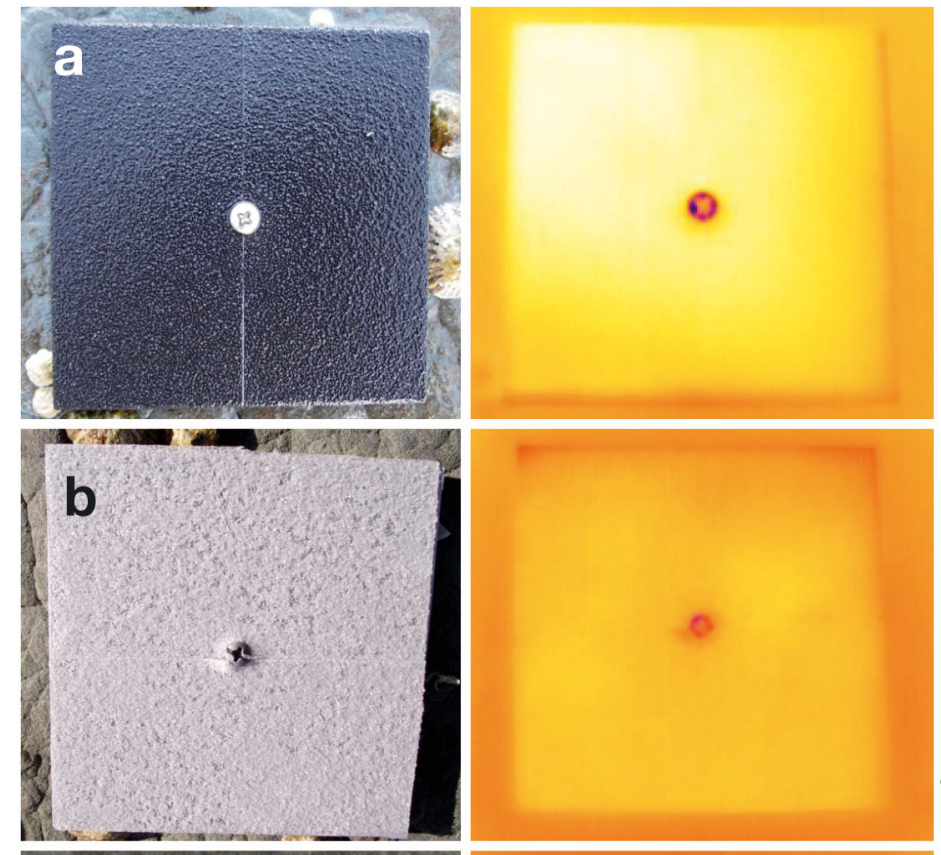

Temp $35^{\circ} \mathrm{C}$
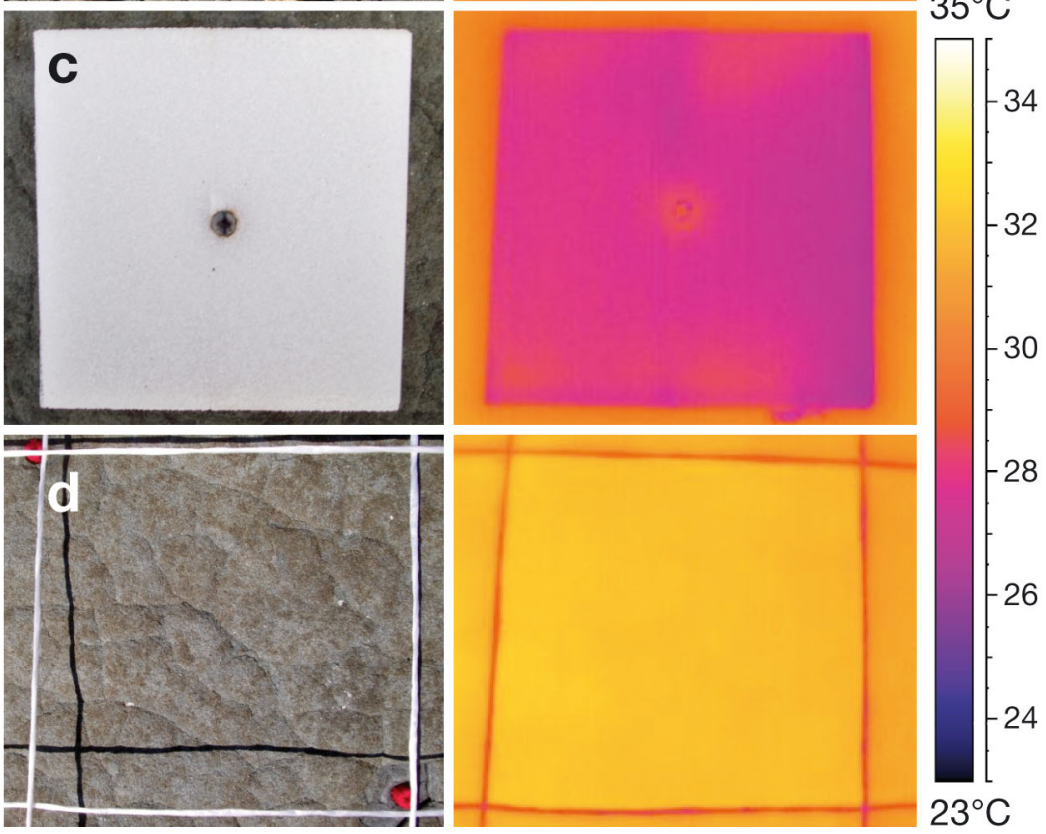

Fig. 1. Photographs and infrared images of (a) black, (b) grey, and (c) white settlement plates and (d) natural rock. Infrared images were taken between 11:00 $\mathrm{h}$ and 12:00 h (low tide: 11:45 h) on 16 March 2011 when ambient air temperatures were on average $31.7^{\circ} \mathrm{C}$ 
of differently coloured rock on settlement of T. rosea, and larvae are, therefore, unlikely to respond to the differently coloured surfaces at settlement. There are, however, minor chemical differences between black SWT, which is made of polyurethane with a solvent, and clear SWT, which is made of polyethylene without a solvent (3M pers. comm.). Note that a simpler choice of materials, such as black, grey and white SWT on grey PVC plates, proved difficult due to the unavailability of all 3 coloured SWT of identical textures. Therefore, to minimise any differences in chemical properties of differently coloured plates and SWT, we thoroughly cleaned the plates using freshwater and allowed them to soak for $24 \mathrm{~h}$ before applying the SWT. Once the SWT was applied, we further conditioned the plates in the field for $3 \mathrm{wk}$ before measuring settlement and early post-settlement processes, allowing natural biofilms to accumulate on all artificial surfaces and natural rock (Qian et al. 2003).

Fifteen plates (5 per treatment) were allocated haphazardly and screwed onto horizontal to slightly sloping emergent rock, 1 to $2 \mathrm{~m}$ apart, at mid-intertidal heights characterised by moderate to high adult densities at Garie Beach on 7 March 2011. Five permanent quadrats of natural rock were also established at the same tidal height and interspersed among the 15 settlement plates. Sites were constrained to be horizontal to slightly sloping emergent rock with at least $400 \mathrm{~cm}^{2}$ area of flat surface without crevices or depressions that could retain water during low tide. We monitored plates daily while they were being conditioned in the field, and no barnacles were observed to have settled on plates or rock during this conditioning period. Therefore, we did not need to remove any settlers before the start of the experiment.

\section{Measuring substratum temperatures using infrared imaging}

To measure rock and plate temperatures, infrared (IR) images were taken using a digital IR camera (FLIR S65 ThermaCAM) fitted with a germanium coated lens, which captures wavelengths between 7.5 and $13 \mu \mathrm{m}$ using a focal plane array uncooled microbolometer detector. Images were taken of quadrats $10 \times 10 \mathrm{~cm}$ in size from $50 \mathrm{~cm}$ above the substratum, with each laser beam producing an arc length of 1.3 milliradians when the camera was held $1 \mathrm{~m}$ away from the point of contact. Therefore, each IR image had a spatial resolution of $<1 \mathrm{~mm}^{2}$ per pixel. Measurements at these scales allowed comparison of rock temperature variability both within and among plates and quadrats. Importantly, measurements of rock temperature at this extremely fine $(\mathrm{mm})$ scale should reflect the thermal stresses experienced by recently settled barnacles (Lathlean et al. in press).

The thermal resolution of the IR camera was $0.08^{\circ} \mathrm{C}$ at $30^{\circ} \mathrm{C}$, and by recalibrating the camera every $\sim 2 \mathrm{~min}$, the accuracy of IR measurements was $\pm 0.2^{\circ} \mathrm{C}$. Emissivity $(\varepsilon)$ was set at 0.95 as previous studies demonstrate that $\varepsilon$ values of rocky substrata and invertebrates on intertidal shores typically vary between 0.95 and 1 (Denny \& Harley 2006, Chapperon \& Seuront 2011, Cox \& Smith 2011). The $\varepsilon$ of polyurethane and polyethylene products (i.e. black and clear SWT, respectively) generally vary between 0.95 and 0.97 depending on ambient conditions (J. A. Lathlean pers. obs.). Altering $\varepsilon$ values between 0.95 and 0.97 typically produced a $0.6^{\circ} \mathrm{C}$ difference in plate temperatures (data not shown). Therefore, differences due to $\varepsilon$ values would not have significantly influenced our results. To avoid the potential effects of reflectance on estimates of rock and plate temperature, all quadrats and plates were shaded while IR images were being taken. Nevertheless, because variations in $\varepsilon$ and reflectance can influence the accuracy of IR temperature measurements, groundtruthing was undertaken comparing rock temperatures from IR images and a digital thermocouple (Dick Smith Electronics Digital Multimeter, P/N: Q1574). Both instruments were used to record rock temperatures within the mid-shore region at Garie Beach during low tide. Rock temperatures during this ground-truthing period ranged from $19^{\circ} \mathrm{C}$ to $31^{\circ} \mathrm{C}$, which was similar to the range of temperatures experienced during the study period. A linear regression confirmed a strong and direct relationship between the temperatures measured with the IR camera and the digital thermocouple $\left(\mathrm{r}^{2}=0.84, \mathrm{p}<0.001, \mathrm{n}=40\right)$. This significant linear regression between temperatures recorded by the IR camera $\left(T_{\mathrm{IR}}\right)$ and the digital thermocouple $\left(T_{\mathrm{C}}\right)$ can be represented as $T_{\mathrm{IR}}=(0.904$ $\left.\times T_{\mathrm{C}}\right)+2.625$. Rock temperatures recorded by the IR camera were on average $0.2^{\circ} \mathrm{C}$ higher than rock temperatures recorded by the digital thermocouple.

To compare differences in substratum temperatures of the 4 substratum types, we took a single IR image of each replicate ( $\mathrm{n}=5$ quadrats/plates) on each sampling date $(\mathrm{n}=16$ dates) during low tide and haphazardly sub-sampled and averaged the temperatures of 30 pixels within each image using the software package ThermaCAM Researcher PRO 2.9. Mean temperatures of replicates were then used to calculate the mean temperatures of treatments for each sampling date. 


\section{Early life history processes}

To test the effect of temperature and artificial surfaces on the early life history processes of Tesseropora rosea, we estimated settlement, early post-settlement growth, survival and recruitment by tracking individual barnacles. Using a high resolution digital camera (Fujifilm S9600), photographs of plates and rock were taken daily between 7 March and 2 April and then weekly from 3 to 20 April 2011. The first pulse of settlers arrived after several days of strong wave action on 24 March, with numbers of settlers gradually decreasing through to the 2 April. Using daily images of the plates and rock, newly settled larvae and metamorphosed individuals were identified and individually tracked by digitally mapping their positions and orientations as they settled on a given day during the $10 \mathrm{~d}$ period of settlement. Settlement was therefore calculated as the total number of recently settled cyprids or metamorphosed $T$. rosea larvae observed on settlement plates or rock from 24 March to 2 April 2011, including empty tests of individuals that had settled, metamorphosed and died.

For 3 daily cohorts of settlers, we calculated early post-settlement survival as the percentage of 30 randomly selected individuals that settled on plates or rock on 28, 29 and 31 March that were still alive on 14 April. These 3 cohorts comprised $52 \%$ of the total settlement during the $10 \mathrm{~d}$ settlement period and, therefore, are representative of the majority of individuals that settled during the sampling period. Similarly, to measure early post-settlement growth, the maximum test length of individuals from 3 daily cohorts that settled on 28, 29 and 31 March were measured on 14 April (between 10 and 25 individuals were measured on each plate, depending on availability, to obtain a single growth estimate for each replicate plate). Because all individuals within a cohort settled and metamorphosed on the same day, differences in maximum test length were attributed to differential growth, not age. Maximum test length was measured instead of aperture length because at this early age the apertures of Tesseropora rosea settlers are often difficult to distinguish from the test. Finally, recruitment, the end product of larval settlement and early post-settlement survival, was estimated by counting the total number of $T$. rosea that settled on plates and rock between 24 March and 2 April (i.e. during the period when settlement was recorded) that were still alive on 14 April.

\section{Data analysis}

We used 2-way analysis of variance (ANOVA) to test whether the 4 substrata (3 differently coloured settlement plates and natural rock) experienced different temperatures and whether these differences varied depending on the date measurements were taken. One-way ANOVA was used to test for differences in settlement, early post-settlement growth, survival and recruitment of Tesseropora rosea among the 4 substrata. Because estimates of growth and survival for the 3 different daily cohorts were measured across different durations, we undertook separate 1way ANOVA and post-hoc comparisons for each of the 3 daily cohorts. Where significant differences were found with ANOVA, Student-Neuman-Keuls (SNK) tests were used to determine differences in temperatures and early life history processes among treatments. We also wanted to test separately for differences among the 3 artificial surfaces (i.e. excluding natural rock), but statistical comparisons among plates were the same regardless of whether rock was included as a treatment, so analyses including rock are presented here. We confirmed that the data were normally distributed and showed equal variance using the Shapiro-Wilks test for normality and Cochran's test, respectively, and therefore, data were not transformed.

\section{RESULTS}

\section{Manipulation of substratum temperatures}

Substratum temperatures were significantly different among the 4 substratum types, but differences varied depending on the date temperature measurements were taken (interaction of substratum type $x$ sampling date: $\left.F_{45,240}=7.17, \mathrm{p}<0.001\right)$. Over the entire sampling period, black and white plates differed by up to $5.8^{\circ} \mathrm{C}$, with an average difference of $2.2^{\circ} \mathrm{C}$, confirming the hypothesis that plate colour alters substratum temperatures. Moreover, black plates were significantly hotter than all other treatments, and grey plates and rock were significantly hotter than white plates (SNK tests). Consequently, the thermal properties of natural rock were most similar to those of grey plates (Fig. 2).

When substratum temperatures were analysed separately for each day, we detected significant differences among treatments for 11 of the 16 sampling dates, with hotter dates showing greater differences among substrata than cooler dates (SNK tests) 


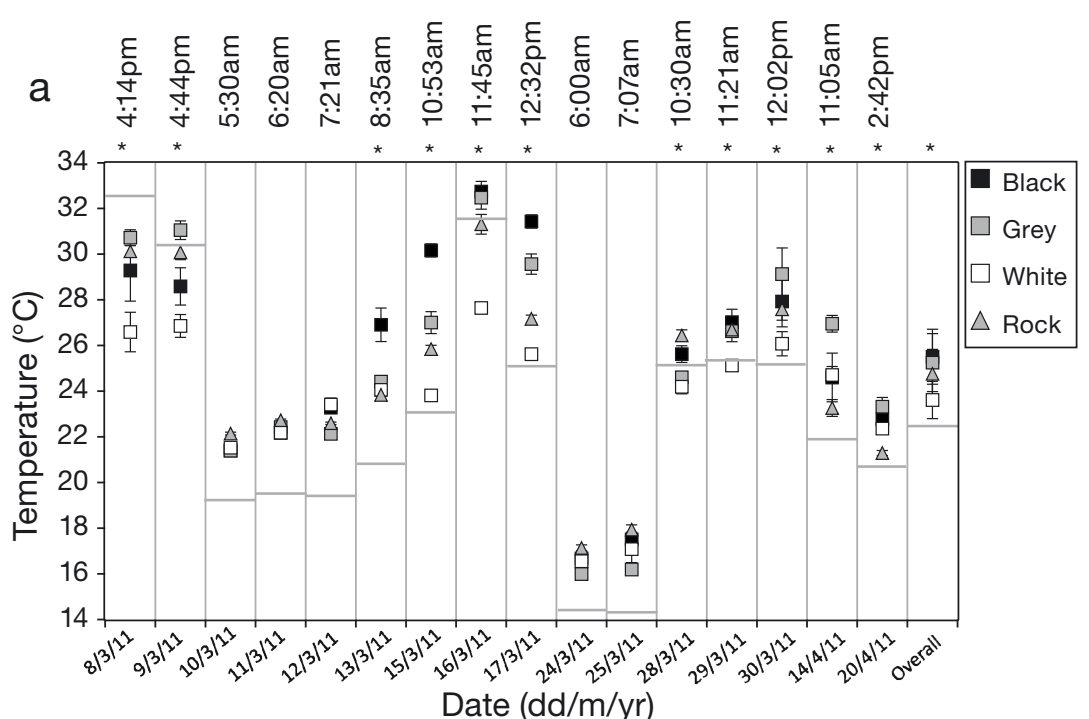

b

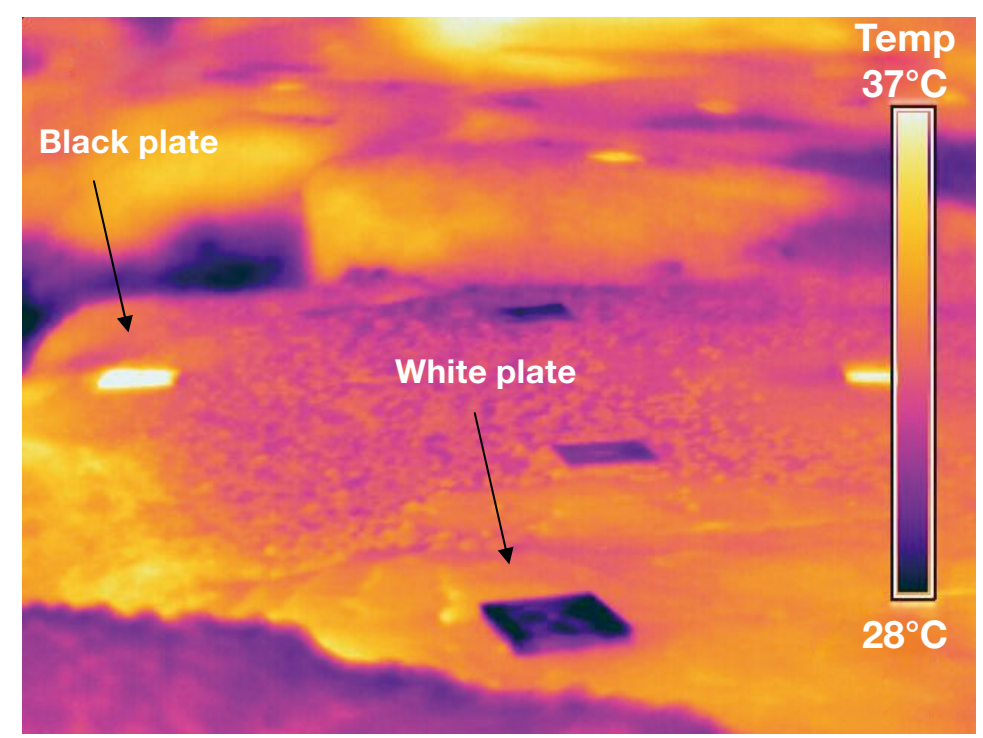

Fig. 2. (a) Mean $( \pm 1 \mathrm{SE})$ temperature of black, grey and white settlement plates and natural rock measured from infrared (IR) images taken at low tide between 8 March and 20 April 2011. Horizontal lines indicate the mean air temperatures recorded by in situ data loggers during the time of sampling. Timing of low tide for each sampling date is indicated at the top of each column. Sampling dates marked with an asterisk indicate dates with significant differences among treatments. (b) IR image of plates in the field on 16 March 2011

(Fig. 2). In general, black and grey plates and rock were consistently hotter than white plates, and these differences were most obvious on 15, 16, 17, 29 and $30 \mathrm{March}$, when low tides fell between 10:53 $\mathrm{h}$ and $12: 32 \mathrm{~h}$ and ambient air temperatures varied between 22 and $32^{\circ} \mathrm{C}$ (SNK tests) (Fig. 2). The most pronounced temperature differences occurred on 17 March as the temperatures of black, grey and white plates and rock were on average 31.4, 29.6, 25.6 and $27.2^{\circ} \mathrm{C}$, respectively (Fig. 2). Interestingly, the sur- face temperatures of grey natural rock were most similar to those of grey plates.

\section{Early life history processes}

From the 24 March to 2 April, settlement of barnacle larvae varied significantly among substrata and was greatest on white and grey settlement plates and least on natural rock $\left(F_{3,17}=3.75, p=0.036\right)$ (Fig. 3a). Larval settlement on white plates varied significantly from settlement on black plates and natural rock. For example, white plates received almost double the number of settlers as black plates and nearly 3 times as many settlers as natural rock (Fig. 3a). Larval settlement on both white and grey plates was also significantly greater than the number of Tesseropora rosea larvae settling on natural rock (Fig. 3a).

Early post-settlement survival varied significantly among treatments and was consistent among all 3 daily cohorts (28 March: $F_{3,18}=6.20, \mathrm{p}=0.006$; 29 March: $F_{3,18}=4.23, \mathrm{p}=0.024 ; 31$ March: $F_{3,18}=5.70, \mathrm{p}=0.008$ ) (Fig. 3b). Mean survival of all 3 cohorts was greatest for larvae that settled on natural rock $(\sim 76 \%)$ and least for larvae that settled on grey plates $(\sim 28 \%)$ (Fig. 3b). Surprisingly, our thermal manipulation did not have a significant effect on early post-settlement survival of settlers on artificial surfaces of different colour (Fig. 3b). In contrast, early post-settlement survival was significantly lower on artificial surfaces compared to natural rock, with survival on black and grey plates almost 2- to 3-fold lower than survival on rock (Fig. 3b). This difference between natural rock and plates suggests that plates might not be appropriate in providing absolute estimates of early post-settlement survival for Tesseropora rosea on natural rock.

For individuals that settled on 28 March, growth varied significantly among the 4 substrata $\left(F_{3,18}=\right.$ 4.26, $\mathrm{p}=0.006$ ) (Fig. 3c). Here, individuals that settled on cooler, white plates were $15 \%$ larger than those on hotter, black plates (Fig. 3c). In contrast, no significant 

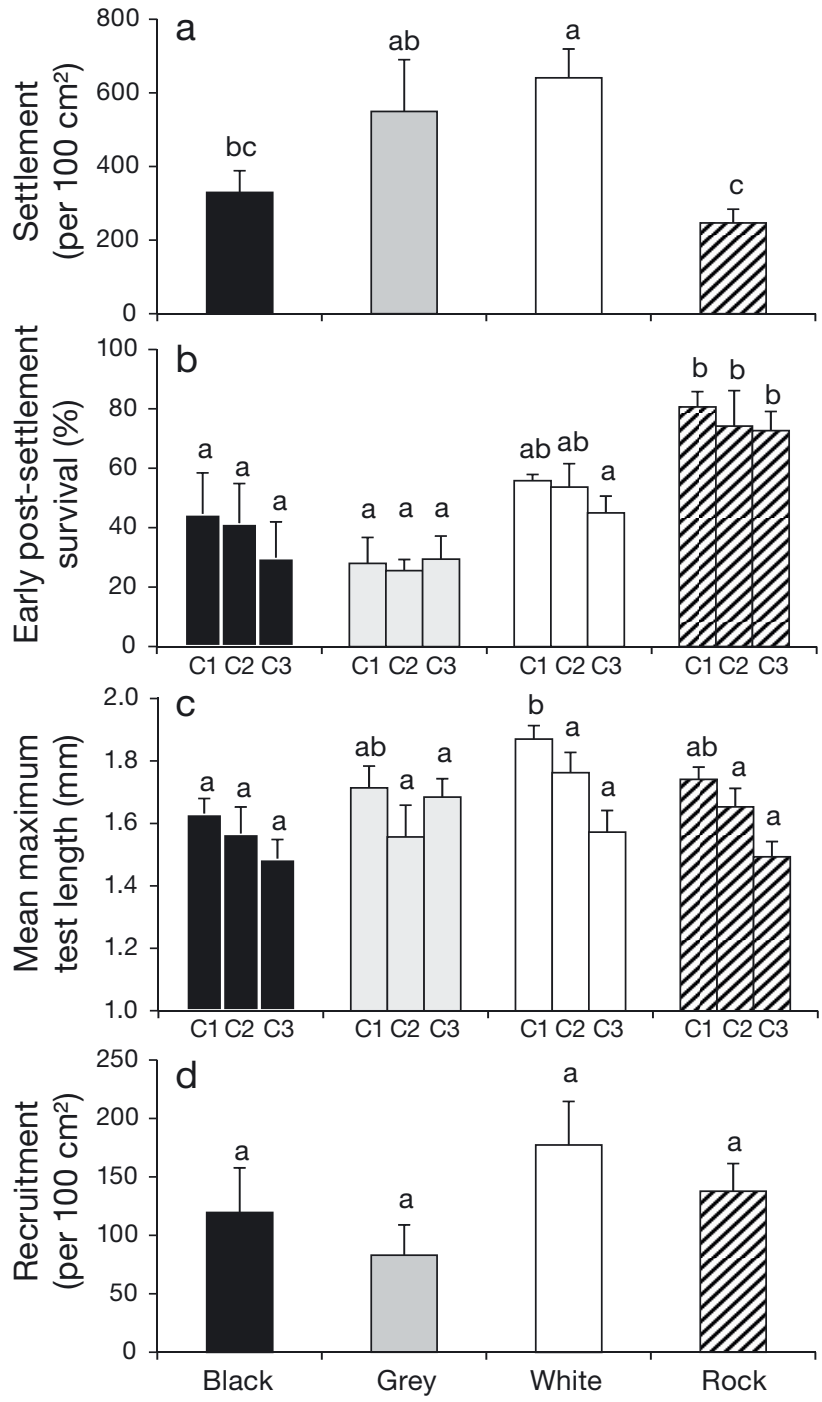

Fig. 3. Tesseropora rosea. (a) Settlement from 24 March to 2 April $(\mathrm{n}=5)$, (b) percentage of daily cohorts that settled on 28 (C1), 29 (C2) and 31 (C3) March that survived to 14 April (n = 5), (c) final maximum test length of the daily cohorts given in panel (b) that survived to 14 April $(\mathrm{n}=5)$ and (d) number of recruits on 14 April $(n=5)$ on settlement plates (black, grey and white) and natural rock. Bars with different letters denote statistically significant differences according to SNK tests. For panels $(\mathrm{b}, \mathrm{c})$, letters only denote differences between the 4 substratum types within each cohort and do not indicate differences among cohorts. Values are means + SE

difference in growth was found when estimates were made using daily cohorts that settled on either 29 or 31 March. Furthermore, unlike settlement and early post-settlement survival, no significant difference was found in the size of settlers on black plates, grey plates and rock, indicating that early growth of Tesseropora rosea on these artificial substrata is equivalent to the early growth on natural rock.
Recruitment was variable but did not vary significantly among substrata with different temperatures $\left(F_{3,18}=1.38, \mathrm{p}=0.287\right)$ (Fig. $\left.3 \mathrm{~d}\right)$. Although not statistically significant, white plates had almost twice the number of recruits compared to grey plates (Fig. 3d). Similar patterns of recruitment among substrata most likely reflect differences in the number of settlers and their subsequent survival. For example, although settlement on rock was relatively low $(246 \pm 38$ settlers quadrat $^{-1}$ ), early post-settlement survival was high $(80 \%)$ and thus resulted in considerable recruitment $\left(138 \pm 24\right.$ recruits quadrat $\left.^{-1}\right)$. In comparison, settlement on grey plates was considerably higher (550 \pm 141 settlers plate $\left.{ }^{-1}\right)$, but due to low survival $(28 \%)$, recruitment was moderate $\left(83 \pm 26\right.$ recruits plate $\left.{ }^{-1}\right)$. The slightly greater number of recruits on white plates (177 \pm 37 recruits plate $\left.{ }^{-1}\right)$ may be largely attributed to greater settlement $(641 \pm 78$ settlers plate $^{-1}$ ) and moderate early post-settlement survival (56\%). Furthermore, comparison of plates with rock indicates that artificial substrata produce similar estimates of recruitment in comparison to rock.

\section{DISCUSSION}

Our successful manipulation of temperature in the field represents a novel approach to experimentally investigating the effect of temperature on rocky intertidal invertebrates. By deploying differently coloured settlement plates coated with clear or black SWT, we manipulated average substratum temperatures by up to $6^{\circ} \mathrm{C}$, with differences being most obvious on hot days. The magnitude of temperature differences obtained by this thermal manipulation is comparable to that reported by Gedan et al. (2011), who, by insulating cobbles into the bedrock, reduced substratum temperature within the mid-intertidal zone by $8^{\circ} \mathrm{C}$, as well as by Bertness \& Leonard (1997), who reduced substratum temperatures by 6 to $9^{\circ} \mathrm{C}$ through shading. Most importantly, we demonstrate that this thermal manipulation significantly influenced early post-settlement growth of the intertidal barnacle Tesseropora rosea, and although not statistically significant, patterns of early survival and recruitment were generally greater on cooler white plates.

\section{Manipulating rocky intertidal temperatures}

Apart from the present study, to our knowledge, only Shanks (2009) and Gedan et al. (2011) have successfully manipulated the temperatures of rocky in- 
tertidal invertebrates without the use of shade or transplantations (but see Allison 2004 for macroalgae). Shanks (2009) discovered that plexiglass settlement plates covered in grey SWT are more thermally stressful than ceramic tiles, while Gedan et al. (2011) demonstrated that cobbles insulated within the bedrock were cooler than equivalent exposed cobbles. It is difficult, however, to manipulate the thermal environment without the outcome being confounded by factors that could influence the variable being measured. For instance, ceramic tiles typically have different rugosity or surface texture than settlement plates covered in SWT, and several studies have found that surface texture significantly influences rates of larval settlement and survival (Shanks 2009, Menge et al. 2010, Savoya \& Schwindt 2010). Likewise, small-scale hydrodynamics around cobbles imbedded within the underlying substratum may differ significantly from exposed cobbles (Guichard et al. 2001), and this in turn may also influence larval settlement (Wright \& Boxshall 1999, but see O'Donnell \& Denny 2008). Our use of differently coloured plates and SWT on emergent rock in the mid shore region ensured that differences in early life history processes among these artificial surfaces were not due to differences in shade, tidal height, substratum texture or small-scale hydrodynamics. Nevertheless, our manipulation of the thermal environment may also be potentially confounded because plates and SWT differed in colour and could thus be chemically different (see 'Early life history processes' below).

\section{Early life history processes}

The effect of temperature and artificial plates on larval settlement, growth, survival and recruitment of Tesseropora rosea varied depending on the life history process being measured. For example, the 3 differently coloured plates significantly influenced larval settlement and growth but not survival and recruitment, whereas only larval settlement and survival were significantly different between natural rock and plates. It is unlikely that substratum temperatures influenced larval settlement directly since larvae arrive during high tide when substratum temperatures are less variable and unlikely to reflect the temperature variability that occurs during low tide. Alternatively, differences in biofilm composition produced by the different thermal regimes may be indirectly responsible for differences in larval settlement (Olivier et al. 2000, Qian et al. 2003). Similarly, Hung et al. (2005) demonstrated that variation in UV expo- sure influences biofilm composition, which in turn influenced the larval settlement of the polychaete Hydroides elegans. Whether or not thermal variability indirectly influences larvae settlement by altering biofilm communities has yet to be empirically tested but could be an important indirect effect of changing temperature conditions.

Substratum colour can also be an important factor influencing the settlement of benthic marine invertebrates (Pawlik 1992). Although barnacle cyprids do not possess colour vision, their simple median eyes are thought to be capable of detecting light direction and intensity (Brusca \& Brusca 2003, but see Visscher \& Luce 1928). Therefore, Tesseropora rosea larvae may indirectly settle in response to colour, not temperature or biofilm, as the intensity of light associated with different colours can be a particularly strong cue. Marine invertebrate larvae use light intensity to differentiate microhabitats that are either exposed or sheltered from damaging UV light (see review by Pawlik 1992). For example, coral and ascidian larvae preferentially settle in dark-shaded areas as a result of negative phototaxis immediately before settlement (Thorson 1964, Young \& Chia 1984, Kuffner 2001). In the present study, however, darker coloured black plates were more thermally stressful than lighter coloured grey and white plates. Therefore, greater settlement on white plates suggests that larvae of $T$. rosea preferentially settle in areas perceived to be exposed to high levels of ambient light, which is what we might expect since adults are found predominantly on emergent rock exposed to full sunlight (Denley \& Underwood 1979). In areas exposed to high levels of ambient light, Caffey (1982) found no difference in the number of $T$. rosea settling on different coloured natural rock substrata. This suggests that $T$. rosea discriminates shaded from sunny areas but not among rocky types exposed to full sunlight. Differences in larval settlement in the present study could also be due to different chemical properties of plates and SWT. We believe this to be unlikely because we used materials that are relatively inert, cleaned the plates before placing them in the field and conditioned them in situ for $3 \mathrm{wk}$ prior to experimentation. Nevertheless, the necessity for such caveats indicates the difficulty of such manipulations in the field.

The greater number of larvae settling on our artificial plates covered in SWT in comparison to the natural substrata supports Menge et al. (2010), who demonstrated that the greater textural complexity of SWT increases settlement and recruitment of the barnacle Balanus glandula in comparison to natural rock. In the present study, plates covered in SWT had 
surface textures (600 to $700 \mu \mathrm{m}$ grain size) coarser than the natural siltstone (4 to $60 \mu \mathrm{m}$ grain size). However, Caffey (1982) found no difference in the amount of Tesseropora rosea settling on light-brown sandstone and dark-grey mudstone, 2 naturally occurring rock types with equivalent grain sizes to SWT and siltstone, respectively. Alternatively, potential differences in settlement between natural and artificial surfaces detected in the present study may be due to differences in biofilm composition or some other factor (Faimali et al. 2004). Regardless, the differences between natural and artificial surfaces detected in the present study suggest a cautionary approach should be taken when interpreting the results of studies that use settlement plates covered in SWT, and indeed any artificial surface, to estimate early life history processes.

For marine invertebrate larvae, the transition from the water column to the intertidal zone is usually characterised by high levels of mortality due to increased heat and desiccation stress (Gosselin 1997, Hunt \& Scheibling 1997). In the present study, however, we found no effect of our thermal manipulation (i.e. differently coloured plates) on early post-settlement survival of Tesseropora rosea even though white plates were up to $5.8^{\circ} \mathrm{C}$ cooler than black plates. In contrast, numerous studies have shown thermal stress to significantly influence the early post-settlement survival and recruitment of intertidal barnacles. For example, Bertness (1989), Bertness et al. (1999a,b) and Gedan et al. (2011) have collectively shown that the survival of recently metamorphosed Semibalanus balanoides is greater (1) within cooler low intertidal regions relative to hotter high intertidal regions, (2) on boulders compared to smaller (and hotter) cobbles and (3) under experimental shade plots and higher macroalgae canopy cover. Interestingly, the $28 \%$ survival of larvae on grey plates with SWT reported within the present study was higher than that reported by Shanks (2009), who found $\sim 10 \%$ survival of newly settled Balanus glandula on settlement plates covered in grey SWT. We also report unusually high $(\sim 76 \%)$ early post-settlement survival of $T$. rosea on natural rock. At times, plates were observed to be dryer than the underlying substratum. Therefore, desiccation stress may have been substantially lower on natural rock than on plates because (1) siltstone is more permeable to water than SWT and (2) the plates were not insulated by surrounding substrata.

Our previous work confirms that $T$. rosea populations at Garie Beach typically experience high rates of early post-settlement survival $(\sim 50 \%)$ in comparison to other populations along the southeast coast of Aus- tralia (0 to 20\%) (see Lathlean et al. 2010). However, this does not explain why we found no difference in early post-settlement survival among our 3 differently coloured plates. Perhaps early post-settlement survival among plates may have varied under a different set of thermal conditions, such as during extreme heat events. Apart from thermal stress, bulldozing by the abundant limpet Cellana tramoserica might also be a source of early mortality for intertidal barnacles in the study region (Jeffery 2003), but this explanation is unlikely because these limpets were rarely observed on plates. Furthermore, for each of the 3 daily cohorts, early post-settlement survival varied consistently among our 4 substratum types. Early post-settlement growth and survival has been shown to vary among daily cohorts of newly settled barnacle larvae due to differences in larval quality (Jarrett \& Pechenik 1997, Pineda et al. 2006), and consequently, it is likely that larvae among daily cohorts in our relatively shortterm study were of similar quality.

Along with increased thermal stress, the transition from the water column to the benthos is also metabolically expensive as larvae typically undergo metamorphosis and rapidly increase in size within the first few weeks after settlement. Like many physiological processes, the early post-settlement growth of Tesseropora rosea was significantly influenced by temperature as individuals on white plates grew significantly more than individuals on hotter grey and black plates. In contrast, laboratory experiments carried out by Findlay et al. (2010a,b) show that temperature has no affect on the early post-settlement growth of the intertidal barnacles Semibalanus balanoides and Elminius modestus, while field studies on intertidal mussels have found increased temperatures to either increase (Blanchette et al. 2007) or decrease adult growth (Petes et al. 2007). Our results suggest that for newly settled T. rosea, increased temperatures prolong the time it takes for juveniles to reach a particular size at which they may be no longer as vulnerable to environmental stress or predation.

\section{Testing the effects of climate change on rocky intertidal shores}

Using settlement plates of different colour but similar texture may provide a useful tool for experimentally investigating how increasing temperatures associated with climate change will affect intertidal populations and communities. For example, field experiments that manipulate temperature are particularly useful for addressing the role of extreme tem- 
perature events on future populations because they directly elevate body temperatures to reflect future scenarios and do not require long-term monitoring or particularly extreme weather to simulate future temperatures (Smale \& Wernberg 2012). Alternatively, range limits are expected to shift towards the poles in response to increasing temperatures (Helmuth et al. 2006b), and large-scale transplant experiments are often used to help understand the factors that limit a species' distribution (e.g. Gilman 2006a). However, transplanted individuals may survive or grow differently than resident individuals due to local adaptations or physical conditions other than temperature. For transplant experiments involving rocky intertidal invertebrates, differently coloured plates could be used to distinguish the effects of geographic region and temperature or simulate future temperature variability. Our thermal manipulation could also be used to examine other ecological processes in the field, including predator-prey interactions and changes in whole species assemblages, both of which are expected to change in response to increasing temperatures (Sanford 1999, Harley 2011).

\section{CONCLUSIONS}

It is clear from the literature (Table 1), and from the results of this experiment, that our empirical understanding of how temperature influences the early life history stages of benthic marine invertebrates has been largely influenced by laboratory studies and limited by our ability to (1) measure in situ temperatures at scales relevant to settlers and recruits and (2) manipulate temperature in the field. Previous work by the present authors attempts to address the first of these 2 issues by measuring ultra-fine scale $\left(1 \mathrm{~mm}^{2}\right)$ temperature variability and relating this thermal variability to the fate of individual settlers. The results indicate that even at such fine spatial scales, thermal variability significantly influences early postsettlement processes (J. A. Lathlean unpubl. data). The present paper, however, presents a possible solution to the latter of the 2 limitations. Our results also indicate that certain early life history processes of intertidal barnacles may be more susceptible to thermal stress than others. Nonetheless, our review of the literature highlights the need for future experimental field work to investigate the effect of temperature on early life history processes of benthic marine invertebrates. We propose that the thermal manipulation techniques developed in the present study could be used to help fill this gap in the literature.
Acknowledgements. We thank R. McWilliam, L. Aguilar and A. Swan for assistance in the field and D. Ayre, A. Johnson, D. Roberts and E. Lathlean for constructive comments on earlier versions of the manuscript. This research was supported by an Australian Research Council's Discovery Project Grant (Project Number DP0666787) to D. J. Ayre and T.E.M., a University of Wollongong postgraduate scholarship to J.A.L. and by the Institute for Conservation Biology and Environmental Management at the University of Wollongong.

\section{LITERATURE CITED}

Allison G (2004) The influence of species diversity and stress intensity on community resistance and resilience. Ecol Monogr 74:117-134

Bertness MD (1989) Intraspecific competition and facilitation in a northern acorn barnacle population. Ecology 70 : 257-268

Bertness MD, Leonard GH (1997) The role of positive interactions in communities: lessons from intertidal habitats. Ecology 78:1976-1989

Bertness MD, Leonard GH, Levine JM, Bruno JF (1999a) Climate-driven interactions among rocky intertidal organisms caught between a rock and a hot place. Oecologia 120:446-450

Bertness MD, Leonard GH, Levine JM, Schmidt PR, Ingraham AO (1999b) Testing the relative contribution of positive and negative interactions in rocky intertidal communities. Ecology 80:2711-2726

> Blanchette CA, Gaines SD (2007) Distribution, abundance, size and recruitment of the mussel, Mytilus californianus, across a major oceanographic and biogeographic boundary at Point Conception, California, USA. J Exp Mar Biol Ecol 340:268-279

Blanchette CA, Helmuth B, Gaines SD (2007) Spatial patterns of growth in the mussel, Mytilus californianus, across a major oceanographic and biogeographic boundary at Point Conception, California, USA. J Exp Mar Biol Ecol 340:126-148

> Blanchette CA, Miner CM, Raimondi PT, Lohse D, Heady KEK, Broitman BR (2008) Biogeographical patterns of rocky intertidal communities along the pacific coast of North America. J Biogeogr 35:1593-1607

Broitman BR, Navarrete SA, Smith F, Gaines SD (2001) Geographic variation of southeastern Pacific intertidal communities. Mar Ecol Prog Ser 224:21-34

Broitman BR, Blanchette CA, Gaines SD (2005) Recruitment of intertidal invertebrates and oceanographic variability at Santa Cruz Island, California. Limnol Oceanogr 50: 1473-1479

Broitman BR, Mieszkowska N, Helmuth B, Blanchette CA (2008) Climate and recruitment of rocky shore intertidal invertebrates in the eastern north Atlantic. Ecology 89: S81-S90

Brusca RC, Brusca GJ (2003) Invertebrates, 2nd edn. Sinauer Associates, Sunderland, MA

Burnaford JL (2004) Habitat modification and refuge from sublethal stress drive a marine plant-herbivore association. Ecology 85:2837-2849

Burrows MT, Jenkins SR, Robb L, Harvey R (2010) Spatial variation in size and density of adult and post-settlement Semibalanus balanoides: effects of oceanographic and local conditions. Mar Ecol Prog Ser 398:207-219

Caddy-Retalic S, Benkendorff K, Fairweather PG (2011) Visualizing hotspots: applying thermal imaging to moni- 
tor internal temperatures in intertidal gastropods. Molluscan Res 31:106-113

Caffey HM (1982) No effect of naturally-occurring rock types on settlement or survival in the intertidal barnacle, Tesseropora rosea (Krauss). J Exp Mar Biol Ecol 63:119-132

Caley MJ, Carr MH, Hixon MA, Hughes TP, Jones GP, Menge BA (1996) Recruitment and the local dynamics of open marine populations. Annu Rev Ecol Syst 27:477-500

> Carrington E, Moeser GM, Dimond J, Mello JJ, Boller ML (2009) Seasonal disturbance to mussel beds: field test of a mechanistic model predicting wave dislodgment. Limnol Oceanogr 54:978-986

Chan BKK, Morritt D, De Pirro M, Leung KMY, Williams GA (2006) Summer mortality: effects on the distribution and abundance of the acorn barnacle Tetraclita japonica on tropical shores. Mar Ecol Prog Ser 328:195-204

Chapman MG, Underwood AJ (1996) Influences of tidal conditions, temperature and desiccation on patterns of aggregation of the high-shore periwinkle, Littorina unifasciata, in New South Wales, Australia. J Exp Mar Biol Ecol 196:213-237

> Chapperon C, Seuront L (2011) Space-time variability in environmental thermal properties and snail thermoregulatory behaviour. Funct Ecol 25:1040-1050

> Chomsky O, Kamenir Y, Hyams M, Dubinsky Z, ChadwickFurman NE (2004) Effects of temperature on growth rate and body size in the Mediterranean Sea anemone Actinia equina. J Exp Mar Biol Ecol 313:63-73

$>$ Cole VJ (2010) Alteration of the configuration of bioengineers affects associated taxa. Mar Ecol Prog Ser 416: $127-136$

> Connell JH (1985) The consequences of variation in initial settlement vs. post-settlement mortality in rocky intertidal communities. J Exp Mar Biol Ecol 93:11-45

Cox TE, Smith CM (2011) Thermal ecology on an exposed algal reef: infrared imagery a rapid tool to survey temperature at local spatial scales. Coral Reefs 30:1109-1120

> Denley EJ, Underwood AJ (1979) Experiments on factors influencing settlement, survival, and growth of two species of barnacles in New South Wales. J Exp Mar Biol Ecol 36:269-293

> Denny MW, Harley CDG (2006) Hot limpets: predicting body temperature in a conductance-mediated thermal system. J Exp Biol 209:2409-2419

> Denny M, Helmuth B (2009) Confronting the physiological bottleneck: a challenge from ecomechanics. Integr Comp Biol 49:197-201

> Denny MW, Dowd WW, Bilir L, Mach KJ (2011) Spreading the risk: small-scale body temperature variation among intertidal organisms and its implications for species persistence. J Exp Mar Biol Ecol 400:175-190

$>$ Dethier MN, Williams SL, Freeman A (2005) Seaweeds under stress: manipulated stress and herbivory affect critical life-history functions. Ecol Monogr 75:403-418

Faimali M, Garaventa F, Terlizzi A, Chiantore M, CattaneoVietti R (2004) The interplay of substratum nature and biofilm formation in regulating Balanus amphitrite (Darwin, 1854) larval settlement. J Exp Mar Biol Ecol 306:37-50

- Farrell TM, Bracher D, Roughgarden J (1991) Cross-shelf transport causes recruitment to intertidal populations in Central California. Limnol Oceanogr 36:279-288

Findlay HS, Kendall MA, Spicer JI, Widdicombe S (2010a) Post-larval development of two intertidal barnacles at elevated $\mathrm{CO}_{2}$ and temperature. Mar Biol 157:725-735

Findlay HS, Kendall MA, Spicer JI, Widdicombe S (2010b) Relative influences of ocean acidification and temperature on intertidal barnacle post-larvae at the northern edge of their geographic distribution. Estuar Coast Shelf Sci 86:675-682

Fitzhenry T, Halpin PM, Helmuth B (2004) Testing the effects of wave exposure, site, and behavior on intertidal mussel body temperatures: applications and limits of temperature logger design. Mar Biol 145:339-349

> Gedan KB, Bernhardt J, Bertness MD, Leslie HM (2011) Substratum size mediates thermal stress in the rocky intertidal. Ecology 92:576-582

Gilman SE (2006a) Life at the edge: an experimental study of a poleward range boundary. Oecologia 148:270-279

Gilman SE (2006b) The northern geographic range limit of the intertidal limpit Collisella scabra: a test of performance, recruitment, and temperature hypothesis. Ecography 29:709-720

> Gosselin LA (1997) An ecological transition during juvenile life in a marine snail. Mar Ecol Prog Ser 157:185-194

> Gosselin LA, Jones LA (2010) Effects of solar radiation on barnacle settlement, early post-settlement mortality and community development in the intertidal zone. Mar Ecol Prog Ser 407:149-158

> Gosselin LA, Qian PY (1997) Juvenile mortality in benthic marine invertebrates. Mar Ecol Prog Ser 146:265-282

> Guichard F, Bourget E, Robert JL (2001) Scaling the influence of topographic heterogeneity on intertidal benthic communities: alternate trajectories mediated by hydrodynamics and shading. Mar Ecol Prog Ser 217:27-41

Halpin PM, Menge BA, Hofmann GE (2004) Experimental demonstration of plasticity in the heat shock response of the intertidal mussel Mytilus californianus. Mar Ecol Prog Ser 276:137-145

Harley CDG (2003) Abiotic stress and herbivory interact to set range limits across a two-dimensional stress gradient. Ecology 84:1477-1488

Harley CDG (2008) Tidal dynamics, topographic orientation, and temperature-mediated mass mortalities on rocky shores. Mar Ecol Prog Ser 371:37-46

> Harley CDG (2011) Climate change, keystone predation, and biodiversity loss. Science 334:1124-1127

> Harley CDG, Helmuth BST (2003) Local- and regional-scale effects of wave exposure, thermal stress, and absolute versus effective shore level on patterns of intertidal zonation. Limnol Oceanogr 48:1498-1508

> Harley CDG, Lopez JP (2003) The natural history, thermal physiology, and ecological impacts of intertidal mesopredators, Oedoparena spp. (Diptera: Dryomyzidae). Invertebr Biol 122:61-73

Harley CDG, O'Riley JL (2011) Non-linear density-dependent effects of an intertidal ecosystem engineer. Oecologia 166:531-541

- Harley CDG, Hughes AR, Hultgren KM, Miner BG and others (2006) The impacts of climate change in coastal marine systems. Ecol Lett 9:228-241

> Hayworth AM, Quinn JF (1990) Temperature of limpets in the rocky intertidal zone: effects of caging and substratum. Limnol Oceanogr 35:967-970

Helmuth B (1998) Intertidal mussel microclimates: predicting the body temperature of a sessile invertebrate. Ecol Monogr 68:51-74

Helmuth B (1999) Thermal biology of rocky intertidal mussels: quantifying body temperatures using climatological data. Ecology 80:15-34

Helmuth BS, Hofmann GE (2001) Microhabitats, thermal heterogeneity, and patterns of physiological stress in the rocky intertidal zone. Biol Bull 201:374-384

> Helmuth B, Broitman BR, Blanchette CA, Gilman SE and others (2006a) Mosaic patterns of thermal stress in the 
rocky intertidal zone: implications for climate change. Ecol Monogr 76:461-479

Helmuth B, Mieszkowska N, Moore P, Hawkins SJ (2006b) Living on the edge of two changing worlds: forecasting the responses of rocky intertidal ecosystems to climate change. Annu Rev Ecol Evol Syst 37:373-404

- Helmuth B, Broitman BR, Yamane L, Gilman SE, Mach K, Mislan KAS, Denny MW (2010) Organismal climatology: analyzing environmental variability at scales relevant to physiological stress. J Exp Biol 213:995-1003

Helmuth B, Yamane L, Lalwani S, Matzelle A, Tockstein A, Gao N (2011) Hidden signals of climate change in intertidal ecosystems: what (not) to expect when you are expecting. J Exp Mar Biol Ecol 400:191-199

- Herbert RJH, Hawkins SJ (2006) Effect of rock type on the recruitment and early mortality of the barnacle Chthamalus montagui. J Exp Mar Biol Ecol 334:96-108

Herbert RJH, Southward AJ, Sheader M, Hawkins SJ (2007) Influence of recruitment and temperature on distribution of intertidal barnacles in the English Channel. J Mar Biol Assoc UK 87:487-499

- Hidas EZ, Ayre DJ, Minchinton TE (2010) Patterns of demography for rocky-shore, intertidal invertebrates approaching their geographical range limits: tests of the abundant-centre hypothesis in south-eastern Australia. Mar Freshw Res 61:1243-1251

> Hofmann GE, Somero GN (1995) Evidence for protein damage at environmental temperatures: seasonal changes in levels of ubiquitin conjugates and hsp70 in the intertidal mussel Mytilus trossulus. J Exp Biol 198:1509-1518

> Hung OS, Thiyagarajan V, Wu RSS, Qian PY (2005) Effect of ultraviolet radiation on biofilms and subsequent larval settlement of Hydroides elegans. Mar Ecol Prog Ser 304: 155-166

Hunt HL, Scheibling RE (1997) Role of early post-settlement mortality in recruitment of benthic marine invertebrates. Mar Ecol Prog Ser 155:269-301

> Hutchinson N, Williams GA (2003) Disturbance and subsequent recovery of mid-shore assemblages on seasonal, tropical, rocky shores. Mar Ecol Prog Ser 249:25-38

> Jarrett JN, Pechenik JA (1997) Temporal variation in cyprid quality and juvenile growth capacity for an intertidal barnacle. Ecology 78:1262-1265

Jeffery CJ (2003) Determination of abundance and distribution of an intertidal barnacle: settlement or post settlement mortality? Mar Ecol Prog Ser 246:291-305

> Jones SJ, Mieszkowska N, Wethey DS (2009) Linking thermal tolerances and biogeography: Mytilus edulis (L.) at its southern limit on the east coast of the United States. Biol Bull 217:73-85

Jones SJ, Lima FP, Wethey DS (2010) Rising environmental temperatures and biogeography: poleward range contraction of the blue mussel, Mytilus edulis L., in the western Atlantic. J Biogeogr 37:2243-2259

Jorger KM, Meyer R, Wehrtmann IS (2008) Species composition and vertical distribution of chitons (Mollusca: Polyplacophora) in a rocky intertidal zone of the Pacific Coast of Costa Rica. J Mar Biol Assoc UK 88:807-816

$>$ Kawai T, Tokeshi M (2004) Variable modes of facilitation in the upper intertidal: goose barnacles and mussels. Mar Ecol Prog Ser 272:203-213

Keough MJ, Downes BJ (1982) Recruitment of marine invertebrates: the role of active larval choices and early mortality. Oecologia 54:348-352

Kuffner IB (2001) Effects of ultraviolet (UV) radiation on larval settlement of the reef coral Pocillopora damicornis. Mar Ecol Prog Ser 217:251-261
Ladah LB, Tapia FJ, Pineda J, Lopez M (2005) Spatially heterogeneous, synchronous settlement of Chthamalus spp. larvae in northern Baja California. Mar Ecol Prog Ser 302:177-185

Lagos NA, Navarrete SA, Veliz F, Masuero A, Castilla JC (2005) Meso-scale spatial variation in settlement and recruitment of intertidal barnacles along the coast of central Chile. Mar Ecol Prog Ser 290:165-178

> Lagos NA, Tapia FJ, Navarrete SA, Castilla JC (2007) Spatial synchrony in the recruitment of intertidal invertebrates along the coast of central Chile. Mar Ecol Prog Ser 350:29-39

> Lathlean JA, Ayre DJ, Minchinton TE (2010) Supply-side biogeography: geographic patterns of settlement and early mortality for a barnacle approaching its range limit. Mar Ecol Prog Ser 412:141-150

Lathlean JA, Ayre DJ, Minchinton TE (2011) Rocky intertidal temperature variability along the southeast coast of Australia: comparing data from in situ loggers, satellitederived SST and terrestrial weather stations. Mar Ecol Prog Ser 439:83-95

Lathlean JA, Ayre DJ, Minchinton TE (2012) Using infrared imagery to test for quadrat-level temperature variation and effects on the early life history of a rocky-shore barnacle. Limnol Oceanogr 57:1279-1291

> Lathlean JA, Ayre DJ, Minchinton TE (in press) Temperature variability at the larval scale affects early survival and growth of an intertidal barnacle. Mar Ecol Prog Ser

Lima FP, Wethey DS (2009) Robolimpets: measuring intertidal body temperatures using biomimetic loggers. Limnol Oceanogr Methods 7:347-353

McGuinness KA (1989) Effects of some natural and artificial substrata on sessile marine organisms at Galeta Reef, Panama. Mar Ecol Prog Ser 52:201-208

Meager JJ, Schlacher TA, Green M (2011) Topographic complexity and landscape temperature patterns create a dynamic habitat structure on a rocky intertidal shore. Mar Ecol Prog Ser 428:1-12

Menge BA (2000) Recruitment vs. postrecruitment processes as determinants of barnacle population abundance. Ecol Monogr 70:265-288

Menge BA, Chan F, Lubchenco J (2008) Response of a rocky intertidal ecosystem engineer and community dominant to climate change. Ecol Lett 11:151-162

> Menge BA, Chan F, Nielsen KJ, Lorenzo ED, Lubchenco J (2009) Climatic variation alters supply-side ecology: impact of climate patterns on phytoplankton and mussel recruitment. Ecol Monogr 79:379-395

> Menge BA, Foley MM, Pamplin J, Murphy G, Pennington C (2010) Supply-side ecology, barnacle recruitment, and rocky intertidal community dynamics: Do settlement surface and limpet disturbance matter? J Exp Mar Biol Ecol 392:160-175

Menge BA, Gouhier TC, Freidenburg T, Lubchenco J (2011) Linking long-term, large-scale climatic and environmental variability to patterns of marine invertebrate recruitment: toward explaining "unexplained" variation. J Exp Mar Biol Ecol 400:236-249

Miller LP, Denny MW (2011) Importance of behavior and morphological traits for controlling body temperature in littorinid snails. Biol Bull 220:209-223

Minchinton TE, Scheibling RE (1991) The influence of larval supply and settlement on the population structure of barnacles. Ecology 72:1867-1879

> Minchinton TE, Scheibling RE (1993) Variations in sampling procedure and frequency affect estimates of recruitment of barnacles. Mar Ecol Prog Ser 99:83-88 
Monaco CJ, Brokordt KB, Gaymer CF (2010) Latitudinal thermal gradient effect on the cost of living of the intertidal porcelain crab Petrolisthes granulosus. Aquat Biol 9:23-33

> Morelissen B, Harley CDG (2007) The effects of temperature on producers, consumers, and plant-herbivore interactions in an intertidal community. J Exp Mar Biol Ecol 348: 162-173

> Munoz JLP, Camus PA, Labra FA, Finke GR, Bozinovic F (2008) Thermal constraints on daily patterns of aggregation and density along an intertidal gradient in the periwinkle Echinolittorina peruviana. J Therm Biol 33:149-156

Munroe DM, Noda T (2010) Physical and biological factors contributing to changes in the relative importance of recruitment to population dynamics in open populations. Mar Ecol Prog Ser 412:151-162

Murphy RJ, Underwood AJ, Pinkerton MH (2006) Quantitative imaging to measure photosynthetic biomass on an intertidal rock-platform. Mar Ecol Prog Ser 312:45-55

> O'Donnell MJ, Denny MW (2008) Hydrodynamic forces and surface topography: centimeter-scale spatial variation in wave forces. Limnol Oceanogr 53:579-588

Olivier F, Tremblay R, Bourget E, Rittschof D (2000) Barnacle settlement: field experiments on the influence of larval supply, tidal level, biofilm quality and age on Balanus amphitrite cyprids. Mar Ecol Prog Ser 199:185-204

$>$ Pardo LM, Johnson LE (2004) Activity and shelter use of an intertidal snail: effects of sex, reproductive condition and tidal cycle. J Exp Mar Biol Ecol 301:175-191

Pawlik JR (1992) Chemical ecology of the settlement of benthic marine invertebrates. Oceanogr Mar Biol Annu Rev 30:273-335

> Petes LE, Menge BA, Murphy GD (2007) Environmental stress decreases survival, growth, and reproduction in New Zealand mussels. J Exp Mar Biol Ecol 351:83-91

> Pincebourde S, Sanford E, Helmuth B (2008) Body temperatures during low tide alters the feeding performance of a top intertidal predator. Limnol Oceanogr 53:1562-1573

Pineda J, Starczak V, Stueckle TA (2006) Timing of successful settlement: demonstration of a recruitment window in the barnacle Semibalanus balanoides. Mar Ecol Prog Ser 320:233-237

> Pitt NR, Poloczanska ES, Hobday AJ (2010) Climate-driven range changes in Tasmanian intertidal fauna. Mar Freshw Res 61:963-970

Place SP, O'Donnell MJ, Hofmann GE (2008) Gene expression in the intertidal mussel Mytilus californianus: physiological response to environmental factors on a biogeographic scale. Mar Ecol Prog Ser 356:1-14

Power AM, McCrann K, McGrath D, O'Riordan RM, Simkanin C, Myers AA (2011) Physiological tolerance predicts species composition at different scales in a barnacle guild. Mar Biol 158:2149-2160

> Qian PY, Thiyagarajan V, Lau SCK, Cheung SCK (2003) Relationship between bacterial community profile in biofilm and attachment of the acorn barnacle Balanus amphitrite. Aquat Microb Ecol 33:225-237

Raimondi PT (1988) Rock type affects settlement, recruitment, and zonation of the barnacle Chthamalus anisopoma Pilsbury. J Exp Mar Biol Ecol 123:253-267

> Rilov G, Gasith A, Benayahu Y (2005) Effect of disturbance on foraging: whelk activity on wave-exposed rocky shores with minimal tidal range. Mar Biol 147:421-428

Rivadeneira MM, Fernandez M (2005) Shifts in southern endpoints of distribution in rocky intertidal species along the south-eastern Pacific Coast. J Biogeogr 32:203-209

Sanford E (1999) Regulation of keystone predation by small changes in ocean temperature. Science 283:2095-2097

Sanford E (2002) Water temperature, predation, and the neglected role of physiological rate effects in rocky intertidal communities. Integr Comp Biol 42:881-891

Savoya V, Schwindt E (2010) Effect of the substratum in the recruitment and survival of the introduced barnacle Balanus glandula (Darwin 1854) in Patagonia, Argentina. J Exp Mar Biol Ecol 382:125-130

- Schiel DR, Steinbeck JR, Foster MS (2004) Ten years of induced ocean warming causes comprehensive changes in marine benthic communities. Ecology 85:1833-1839

Schneider KR, Helmuth B (2007) Spatial variability in habitat temperature may drive patterns of selection between an invasive and native mussel species. Mar Ecol Prog Ser 339:157-167

> Schoch GC, Menge BA, Allison G, Kavanaugh M, Thompson SA, Wood SA (2006) Fifteen degrees of separation: latitudinal gradients of rocky intertidal biota along the California Current. Limnol Oceanogr 51:2564-2585

> Seabra R, Wethey DS, Santos AM, Lima FP (2011) Side matters: microhabitat influence on intertidal heat stress over a large geographical scale. J Exp Mar Biol Ecol 400:200-208

- Shanks AL (2009) Barnacle settlement versus recruitment as indicators of larval delivery. I. Effects of post-settlement mortality and recruit density. Mar Ecol Prog Ser 385: 205-216

Short AD, Trenaman NL (1992) Wave climate of the Sydney region, an energetic and highly variable ocean wave regime. Mar Freshw Res 43:765-791

Smale DA, Wernberg T (2012) Short-term in situ warming influences early development of sessile assemblages. Mar Ecol Prog Ser 453:129-136

Steinbeck JR, Schiel DR, Foster MS (2005) Detecting longterm change in complex communities: a case study from the rocky intertidal zone. Ecol Appl 15:1813-1832

> Szathmary PL, Helmuth B, Wethey DS (2009) Climate change in the rocky intertidal zone: predicting and measuring the body temperature of a keystone predator. Mar Ecol Prog Ser 374:43-56

> Tapia FJ, Navarrete SA (2010) Spatial patterns of barnacle settlement in central Chile: persistence at daily to interannual scales relative to the spatial signature of physical variability. J Exp Mar Biol Ecol 392:151-159

Thompson RC, Norton TA, Hawkins SJ (2004) Physical stress and biological control regulate the producer-consumer balance in intertidal biofilms. Ecology 85: 1372-1382

Thorson GL (1964) Light as an ecological factor in the dispersal and settlement of larvae of marine bottom invertebrates. Ophelia 1:167-208

> Underwood AJ, Murphy RJ (2008) Unexpected patterns of facilitatory grazing revealed by quantitative imaging. Mar Ecol Prog Ser 358:85-94

> Visscher PJ, Luce RH (1928) Reactions of the cyprid larvae of barnacles to light with special reference to spectral colors. Biol Bull 54:336-350

> Wethey DS, Woodin SA, Hilbish TJ, Jones SJ, Lima FP, Brannock PM (2011) Response of intertidal populations to climate: effects of extreme events versus long term change. J Exp Mar Biol Ecol 400:132-144

> Wright JR, Boxshall AJ (1999) The influence of small-scale flow and chemical cues on the settlement of two congeneric barnacle species. Mar Ecol Prog Ser 183:179-187

Young CM, Chia FS (1984) Microhabitat-associated variability in survival and growth of subtidal solitary ascidians during the first 21 days after settlement. Mar Biol 81: $61-68$ 